\title{
BAROJA Y SCHOPENHAUER: IMPLICACIONES NARRATIVAS DEL MUNDO COMO REPRESENTACIÓN
}

\author{
David ORDÓÑEZ GARCÍA \\ Universidad de Barcelona
}

Peral'Esther

\section{I}

En marzo de 1904, y desde las páginas de Helios, doña Emilia Pardo Bazán señalaba, con su sagaz pero desigual tino crítico, la sensibilidad exacerbada y el rotundo pesimismo que denotaba la joven narrativa modernista:

Por mi parte diría que los nuevos escritores noo son inferiores a los antiguos ni en talento ni en sensibilidad. Acaso tienen hasta percepción más fina de las relaciones y significación de cuanto les rodea. Creyérase, sin embargo, que un genio maléfico les veda expresar y desenvolver esta percepción por modo tan artístico y fuerte como debieran. Agitados por sobreexcitación nerviosa, o abatidos por una especie de indiferente cansancio [...]. Los libros de los jóvenes son, en general, cortos de resuello; revelan fatiga, y proclaman a cada página lo inútil del esfuerzo y la vanidad de todo. Muéstrase esta generación imbuida de pesimismo, con ráfagas de misticismo católico a la moderna (sin fe ni prácticas), y propende a un neorromanticismo que transparenta las influencias mentales del Norte - Nietzsche, Schopenhauer, Maeterlinck- autores que aquí circulan traducidos (pág. 258).

Gracias a su amplio conocimiento de los escritores y pensadores que cstaban en boga en ese momento, doña Emilia ya descubrió, en tan temprana fecha y en una de las primeras reflexiones de conjunto sobre la nueva novela, uno de los estímulos filosóficos en los que se fundamentaba el pensamiento de los nuevos narradores: el pesimismo de Arthur Schopenhauer. 
Schopenhauer fue ampliamente conocido entre la intelectualidad española del fin de siglo. En la obra de Clarín, por ejemplo, late su presencia en muchas de sus páginas, como la crítica ha señalado' ${ }^{\perp}$ La primera traducción española fue Parerga y Paralipomena (trad. Antonio Zozaya, Madrid, 1889). En la revista y editorial de La España Moderna fue traducido con rigor, difundiendo así rápidamente su pensamiento. En 1894 aparece el primer volumen de El mundo como voluntad y representación, completándose la obra con el segundo (1901) y el tercero (1902), en traducción de Antonio Zozaya (Asún 1981-82, pág. 188, y 1991, pág. 229). Miguel de Unamuno tradujo Sobre la voluntad en la naturaleza en 1900 para Rodríguez Serra, y su pensamiento recoge, en varios aspectos, el de Schopenhauer, algunos tan importantes como la teoría nivolesca del bufo trágico². La crítica también ha observado la influencia del pensador de Danzig en Azorín: basta con recordar el título de su novela de 1902, La voluntad.

Sobre Baroja, contamos con dos trabajos impagables: la monumental monografía de Gonzalo Sobejano (1967) y el artículo de E. Inman Fox "Baroja y Schopenhauer: El árbol de la ciencia" (1963). El novelista guipuzcoano encontró, con toda seguridad, en la lectura de El mundo como voluntad y representación, una formulación sólida, razonada y metódica a un problema que sentía como personal: la relación conflictiva entre el hombre sensible y el mundo, entre la conciencia y la realidad. Podemos apreciar ya su huella en las numerosas colaboraciones periodísticas del escritor en el gozne del cambio de siglo y en los cuentos de Vidas sombrías (1900); y, lo que me parece más importante, su tesis doctoral El dolor. Estudio de psicofísica, publicada en 1896, parte de unos principios que revelan una temprana asunción del pensamiento pesimista de Schopenhauer. En la novela de 1901, su máscara autobiográfica Silvestre Paradox lee a varios filósofos con vistas a escribir un tratado de filosofía, concluyendo que "Kant era Kant y Schopenhauer su profeta" (Baroja, 1901, pág. 158); y en 1911, Andrés Hurtado, buscando por

1 Laureano Bonet ha analizado la presencia de las consideraciones schopenhauerianas sobre la música en La Regenta y en varios cuentos de Clarín (1984 y 1985). Cf. también las aportaciones de Sotelo Vázquez para la lectura del cuento Cantbio de luz (1995), y de Lozano Marco para Las dos cajas (1988). En La Regenta se aprecia la presencia de Schopenhauer en el siguiente fragmento: “No, no hay nada - decía aquel tormento de cerebro-; no hay más que un juego de dolores, un choque de contrasentidos que pueden hacer que padezcas infinitamente; no hay razón para que tenga límites esta tortura del espíritu, que duda de todo, de sí mismo también, pero no del dolor que es lo único que llega al que dentro de ti siente, que no sabe cómo es ni lo que es, pero que padece, pues padeces" (II, págs. 522-523). Se trata de la conocida idea del dolor como única conciencia del mundo, por la cual el hombre con más conocimiento y más voluntad es aquel que siente más dolor.

2 Así, en Del sentimiento trágico de la vida podemos leer: "El único misterio verdaderamente misterioso es el misterio del dolor. El dolor es el camino de la conciencia, y es por él como los seres vivos llegan a tener conciencia de sí. Porque tener conciencia de sí mismo, tener personalidad, es saberse y sentirse distinto de los demás seres, y a sentir esta distinción sólo se llega por el choque, por el dolor más o menos grande, por la sensación del propio límite" (págs. 140-141). Compárese con el pasaje de la novela Amor y pedagogía (1902), cuando Avito quema a su hijo ex profeso con una vela para despertar su conciencia a través del dolor (pág. 8I). De imprescindible consulta es el estudio de Antonio Vilanova (1989). 
doquier "una fórmula de vida", "comenzó la lectura de Parerga y Paralipomena, y le pareció un libro casi ameno, en parte cándido, y le divirtió más de lo que suponía" (1911 a, pág. 72). En sus discusiones filosóficas con Iturrioz ya revela el conocimiento de El mundo como voluntad y representación. Años más tarde, en sus confesiones de Juventud, egolatría (1917), Baroja declarará: "El leer el libro Parerga y Paralipomena, me reconcilió con la filosofía. Después compré, en francés, la Crítica de la razón pura, El mundo como voluntad y representación, y algunas otras obras" (pág. 83) ${ }^{3}$. En 1930, y seguramente gracias al asesoramiento del novelista, la editorial Caro Raggio, dirigida por su cuñado, publicó en su "Biblioteca filosófica" la obra cumbre del pensador de Danzig, aunque de manera incompleta.

La crítica no ha insistido lo suficiente en las implicaciones estrictamente discursivas que el pensamiento de Schopenhauer introduce en la novela, en aspectos tan decisivos como la naturaleza de los caracteres, la estructura narrativa y la expresión o el estilo, con los cuales los jóvenes escritores del 98 dinamitan las bases teóricas del Naturalismo. El pensamiento del filósofo alemán se oculta bajo la teoría y la praxis de la literatura simbolista y decadente procedente de Francia.

\section{II}

El modelo narrativo decadentista es, junto con el espiritualista - con su variante el roman d'analyse francés o novela psicológica, que tiene su prototipo en Bourget-, la gran fórmula narrativa que se les ofrece a los jóvenes novelistas como superación del Naturalismo zolesco. Este tipo de novela no ha sido lo suficientemente estudiado por la crítica española — no así por la hispanoamericana-, quizá porque ninguno de nuestros escritores se ajusta perfectamente al modelo francés, À rebours (1884), de Joris-Karl Huysmans. Sin embargo, vestigios de esta fórmula narrativa pueden rastrearse en Unamuno - en su recientemente publicado Nuevo mundo (1896-97)—, en la tetralogía de Antonio Azorín, en las Sonatas de Valle-Inclán, en la última narrativa de Emilia Pardo Bazán, y en Pío Baroja, por supuesto, como vamos a estudiar a continuación.

Lo que principalmente da unidad al modelo narrativo decadentista es el personaje. Se trata del héroe decadente, personaje excepcional que se caracteriza por pertenecer a la aristocracia del espíritu y por encarnar una sensibilidad estética que se contraponen frontalmente con el materialismo utilitario del sistema capitalista y

${ }^{3}$ José Alberich no señala en su estudio qué libros de Schopenhauer poseía el escritor, ni si estaban anotados: "Aparte de la filosofía formativa de su ideología juvenil (Kant, Schopenhauer, Nietzsche), se encuentra una mediana colección de obras más o menos estrictamente filosóficas"; 150 , según su cómputo (págs. 272 y 267). Es probable -pero sólo una hipótesis_, por este testimonio del escritor, que poseyera Parerga y Paralipomena en traducción española de Antonio Zozaya ( I889), y El mundo como voluntad y representación en traducción francesa (París, Félix Alcan, 1888), aunque el volumen fuera comprado en Madrid. 
con la mediocridad de la sociedad burguesa. El héroe decadente, según el modelo francés, es fácilmente relacionable con el personaje de la nueva narrativa que comienza a despuntar hacia 1890 , claramente alejado del prototipo de la medianía, del "personaje indeciso" naturalista: son los caracteres extremos o excepcionales que Clarín, en su fundamental reseña a Realidad de Galdós, juzgaba necesarios para la novela psicológica, dominados por los imperativos de su conciencia y enfrentados a desgarrados conflictos entre materia y espíritu ${ }^{4}$. Su actitud abúlica, su abdicación de toda actividad vital, por un lado, y su refugio en la contemplación artística, por otro, lo ponen en estrecha consonancia, como veremos, con las teorías schopenhauerianas ${ }^{5}$.

En muchas ocasiones, y con mayor razón si hablamos de Baroja, este personaje excepcional será la máscara ficticia del propio autor-narrador, el cual queda implicado, debido a la patencia del mismo en el texto novelesco, en la trama y en cl tema de la obra. Con ello salta en mil pedazos del dogma naturalista de la impersonalidad narrativa, y la novela se adentra así por las sendas del autobiografismo. El novelista vasco declara que es imposible que el autor no refleje la simpatía o la antipatía que siente por sus personajes, ya que son, de una forma u otra, proyecciones autobiográficas:

Es imposible no tener simpatía o antipatía deliberada por los tipos inventados por el autor que, en general, no son más que desdoblamientos de sí mismo, en los cuales se elogia o se denigra con más o menos claridad lo que se inventa.

También se asegura que el autor no debe de hablar nunca por su voz, sino por la de sus personajes, buscando el perder su carácter o identificarse con ellos.

[...] ¿Por qué no ha de haber un género en el cual el autor hable al público como el voceador de figuras de cera en su barraca? (Baroja, 1948, pág. 250)

Esta evolución en el estatuto de los personajes afectará también a su consideración epistemológica: del "hombre como ser natural y social" propio del Naturalismo, estudiado en sus dimensiones física y colectiva, se pasará ahora al "hombre interior". "¡Adentro!”, para decirlo con el título del ensayo unamuniano de 1900, es el nuevo imperativo para autor y personaje (G. Gullón, 1992, págs. 2832).

4 "La novela de costumbres, la social, la que pinta los medios, una clase entera, una profesión, debe escoger los tipos normales [...], porque sólo estas medianías representan bien lo que el autor se ha propuesto estudiar y expresar, mientras la novela psicológica, la que atiende al carácter, necesita siempre, según Bourget, referirse a los extremos [...], a los seres excepcionales, en los que no se estudia un término medio de su género, sino una individualidad bien acentuada, original y aparte" (La España Moderna, III-1890; 1892, pág. 241). Cf. Sotelo Vázquez (1991).

5 Contamos con una reciente aportación de Nil Santiáñez-Tió (1995). Se trata de un importante trabajo de caracterización, pero tiene el problema de extender su análisis retrospectivamente hasta el Romanticismo y el Realismo-Naturalismo; al menos en este último movimiento no es el héroe decadente el centro de interés principal de la novela, sino la imitación del movimiento de la vida. Por ello debería reservarse el marbete héroe decadente únicamente para la narrativa finisecular o modernista. 
La reacción idealista o espiritualista --en su doble faceta ética o estética que le confiere la herencia krausista - en contra de las formas de vida que caracterizan a la sociedad burguesa surgida tras el fracaso del Sexenio revolucionario (1868-74) y consolidada con la Restauración borbónica, dominadas por el pragmatismo o utilitarismo en sus vertientes sociales, políticas, económicas e incluso culturales, es una constante que domina y permite reunir en un frente común las diferentes vías de desarrollo de la estética modernista. Este rechazo, surgido desde dentro mismo de la clase burguesa, condicionará las diferentes máscaras con que se expresa la rebeldía de los héroes modernistas, como el dandy (como el marqués de Bradomín en las Sonatas), el bohemio (como Silvestre Paradox), el intelectual abúlico (como Eugenio Rodero en Nuevo mundo, Antonio Azorín o Andrés Hurtado), el activista político (como Ángel Guerra), el artista (como Silvio Lago o Fernando Ossorio) o el golfo (como Manuel, en La busca).

Esta conciencia del abismo existente entre los anhelos o querencias del alma - la voluntad - y los destinos que la sociedad puede ofrecer es la base del pesimismo del héroe modernista. Pesimismo que cabe entender como una actitud vital, y que nace de la conciencia del dolor ocasionado por el deseo insatisfecho, por el ejercicio de la voluntad. En palabras de Schopenhauer:

Todo querer procede de una necesidad, es decir, de una privación, esto es, de un sufrimiento. La satisfacción le pone fin; pero por cada deseo satisfecho, hay por lo menos diez contrariados; además, el deseo es prolongado y sus aspiraciones tienden al infinito; la satisfacción es corta y medida parsimoniosamente. Pero ese contento supremo no es más que aparente tampoco; un deseo satisfecho deja inmediatamente su lugar a un nuevo deseo; el primero es una decepción conocida, el segundo es una decepción no conocida aún. No hay satisfacción de deseo alguno que pueda producir un contento duradero e inalterable [...]. En tanto que nuestra conciencia está henchida por nuestra voluntad, en tanto que estamos sometidos al impulso de un deseo, a las esperanzas y a los temores continuos que él engendra, en tanto que estamos sujetos al querer, no hay para nosotros ni felicidad duradera ni reposo (1819, pág. 276). ${ }^{6}$

Este pensamiento encarnado en personaje tiene su mejor ejemplo en Andrés Hurtado, para quien "el pesimismo de Schopenhauer era una verdad casi matemática" (Baroja, 1911a, pág. 81):

Uno tiene la angustia, la desesperación de no saber qué hacer con la vida, de no tener un plan, de encontrarse perdido, sin brújula, sin luz adonde dirigirse. ¿Qué se hace con la vida? ¿Qué dirección se le da? Si la vida fuera tan fuerte que le arrastrara a uno, el pensar sería una maravilla, algo como para el caminante detenerse y sentarse a la sombra de un árbol, algo como penetrar en un oasis de paz; pero la vida es estúpida, sin emociones, sin accidentes, al menos aquí, y

6 Pesimismo que, si bien fue formulado por Schopenhauer, es de clara raigambre romántica. Nil Santiáñez-Tió ha rastreado su origen en la Fenomenología del espíritu de Hegel y en Schiller (págs. 183-184). 
creo que en todas partes, y el pensamiento se llena de terrores como compensación a la esterilidad emocional de la existencia (págs. 167-168).

La vida consiste, para los personajes barojianos, en una perpetua lucha por el autoconocimiento, en un intento por explicarse su yo, su conciencia, un afán constante por llegar al esclarecimiento de la personalidad, y los textos intentan informar del contraste existente entre las altas aspiraciones del yo y los estrechos horizontes que ofrece una realidad degradada social y moralmente. Silvestre Paradox, Fernando Ossorio, el mayorazgo Juan, Manuel y su hermano Juan, Quintín..., son personajes conflictivos y en continua evolución, personajes excepcionales cuya única realidad es su conciencia.

\section{III}

Es ya un hecho constatado por la crítica más solvente el traslado del eje epistemológico en el Modernismo de la realidad exterior a la conciencia interior ${ }^{7}$. El mundo queda reducido a meros fragmentos, necesariamente inconexos, que una conciencia percibe y por los que se siente afectada: sensaciones discontinuas, fragmentos que corresponden a momentos de percepción intensa. Leemos este presupuesto básico en las páginas de La voluntad:

- La sensación crea la conciencia; la conciencia crea el mundo. No hay más realidad que la imagen, ni más vida que la conciencia. No importa —con tal de que sea intensa- que la realidad interna no acople con la externa. El error y la verdad son indiferentes. La imagen lo es todo (Martínez Ruiz, 1902, pág. 74).

Palabras que traducen fielmente la premisa inicial de Schopenhauer:

El mundo es mi representación. Esta proposición es una verdad para todo ser que vive y conoce, aunque sólo se transforma en un conocimiento abstracto y reflexivo en el hombre. En cuanto éste es capaz de hacer tal transformación, se puede decir que ha nacido en él el sentido filosófico. Entonces posee la plena certidumbre de que no conoce un sol ni una tierra, sino sólo unos ojos que ven ese sol, unas manos que tocan esa tierra; sabe, en una palabra, que el mundo que lo circunda no existe más que como representación respecto al ser que lo perci.be, que es el hombre mismo [...]. Ninguna verdad, pues, más cierta, más absoluta, más evidente que ésta: todo lo existente existe por la idea que de ello se tiene; es decir, el universo entero no es objeto sino en relación con el sujeto, percepción, sino respecto de la inteligencia que lo percibe; en una palabra, es pura representación (1819, pág. 33).

7 "El final del siglo venía marcado en Francia - ha escrito Juan Oleza- por un discurso que ponía en cuestión la primacía de la ciencia, proclamaba la conciencia como primer mecanismo del conocimiento, por encima de la razón y de la experiencia, y con ella arrastraba a un primer plano epistemológico la intuición, la voluntad o el impulso vital bergsoniano, trasladaba al mundo interior o espiritual la verdadera esencia de lo real, abandonando la larga hegemonía de la materia" (1989, págs. 79-80). 
Baroja asumió tempranamente esta premisa schopenhaueriana. Como afirma en las "Divagaciones casi trascendentales" que preceden a César o nada (1910):

Lo individual es la única realidad en la naturaleza y en la vida [...].

Sólo el individuo existe por sí y ante sí. Soy, vivo, es lo único que puede afirmar el hombre.

En lo humano, como en toda la naturaleza, el individuo es lo único. Sólo lo individual existe en el campo de la vida y en el campo del espíritu (pág. 7).

Los personajes de Baroja son conscientes de esta idea, como Fernando Ossorio, cuyas reflexiones presentan evidentes ecos del conocido monólogo de Hamlet:

- ¿Qué es la vida? ¿Qué es vivir? ¿Moverse, ver, o el movimiento anímico que produce el sentir? Indudablemente es esto: una huella en el alma, una estela en el espíritu, y entonces, ¿qué importa que las causas de esta huella, de esta estela, vengan del mundo de adentro o del mundo de afuera? Además, ei mundo de afuera no existe; tiene la realidad que yo le quiero dar (Baroja, 1902, pág. 133).

Esta nueva premisa provocará una serie de cambios en los presupuestos narrativos del Modernismo. La sólida estructura de la novela naturalista quedará herida de muerte. El método de la experimentación artística, que se proponía imitar en la morfología de la novela el movimiento de la vida -léase "vida exterior"quedará ahora sustituido por lo que vengo llamando psicomorfología (en oposición a biomorfología, neologismo acuñado por Sobejano, 1988, pág. 597) o imitación de los movimientos ondulantes de la conciencia, y esta aventura interior será el único hilo estructurante de la novela, el único factor de unidad - necesariamente de tono- del discurso novelesco. Para decirlo con las palabras de José-Carlos Mainer, "la novela es la dispersión de la realidad enhebrada por la tensión receptiva de un alma" (1974, pág. 33). Todas las ficciones barojianas responden a esta fórmula. La realidad representada es, entonces, subjetiva, tamizada por la conciencia (del narrador, del personaje, del narrador-personaje). El sostén epistemológico de la novela ya no es la realidad que se pretende imitar, sino la conciencia interior.

Ahora bien, siguiendo a Schopenhauer, y tras aceptar la premisa básica de su argumentación (el mundo no es sino representación) y que el hombre que tiene voluntad está condenado a no tener nunca reposo, el filósofo distingue dos formas de conocimiento: una sujeta a la voluntad y otra sujeta a la intuición, es decir,

cuando se cesa de buscar a la luz de las diversas expresiones del principio de razón las solas relaciones de los objetos entre sí, relaciones que se reducen siempre en último análisis a la relación de los objetos con nuestra propia voluntad, es decir, cuando no se considera ya ni el lugar, ni el tiempo, ni el por qué, ni el para qué de las cosas, sino pura y simplemente su naturaleza (1819, pág. 253).

Si el sujeto es capaz de olvidarse de su voluntad y del principio de razón, y dedicarse sólo a la contemplación desinteresada de la realidad, de tal modo "que aquél y ésta se confundan en un solo ser, en una sola conciencia totalmente llena y 
acaparada por una visión única e intuitiva", ese sujeto contemplador ya no será individuo, sino "sujeto consciente, puro, emancipado de la voluntad, del dolor y del tiempo" (1819, pág. 254) y, por lo tanto, habrá encontrado el reposo espiritual o ataraxia, habrá cesado su sufrimiento y su dolor anulando su razón, vehículo necesario de su voluntad, en aras de la contemplación desinteresada:

Pero si surge una circunstancia exterior, o bien una impulsión interna que nos transporta muy lejos del torrente infinito del querer, que arranca el conocimiento de la servidumbre de la voluntad, ya nuestra atención no se fijará en los motivos del querer; seremos por completo felices (1819, pág. 276).

Las contradicciones interiores de los héroes barojianos nacen justamente de esta doble forma de conocimiento o de actitud vital: la volitiva y la contemplativa ${ }^{8}$. El hombre de acción y el hombre contemplativo, el héroe activo y el pasivo. Gonzalo Sobejano ve tras esta contradicción la presencia de Nietzsche y de Schopenhauer: "los principales personajes de Baroja, como se ha advertido tantas veces, o son sujetos contemplativos que reproducen el auténtico modo de ser del novelista o criaturas lanzadas a la acción por la acción" (1967, pág. 357). Las dos querencias filosóficas de nuestro novelista se encuentran tras los modelos de sus personajes. Pero el esquema voluntad-contemplación, como hemos visto, procede de Schopenhauer. De aquí parten diferentes contradicciones inherentes a la conciencia del personaje barojiano: inteligencia-vida, reflexión-acción, acción-reposo, y, en la retórica del texto, narración-descripción, como veremos en seguida.

La actitud contemplativa consiste, en el texto de la novela, en verter el conocimiento del mundo que obtiene un individuo sensible -el héroe decadente-, en privilegiados momentos de percepción de esa realidad. Las instancias del relato - velocidad, distancia y perspectiva narrativas - se encargan de traducir, en el terreno de la forma o de la retórica, los resultados de ese mundo visto como mera representación. En estas ocasiones, el texto se empapa de lirismo, dado que, por un lado, la realidad representada aparece tamizada por la conciencia del personaje, por su subjetividad, y por otro, sobre todo, el lenguaje traduce las emociones y querencias de ese personaje, apelando al sentimiento - no a la razón-del lector ${ }^{9}$. Baroja lo explica metanarrativamente en un pasaje de El árbol de la ciencia. Andrés, fervoroso defensor del mundo como representación schopenhaueriano, replica a su tío Iturrioz, quien le ha dicho que eso son "fantasías":

—No, no, realidades — replicó Andrés-. ¿Qué duda cabe que el mundo que conocemos es el resultado del reflejo de la parte del cosmos del horizonte

En palabras de Iturrioz, "ante la vida no hay más que dos soluciones prácticas para el hombre sereno: o la abstención y la contemplación indiferente de todo o la acción limitándose a un círculo pequeño" (Baroja, 1911a, pág. 132).

" Como ha definido Lázaro Carreter, la lírica "consiste, no tanto en la expresión de la subjetividad del poeta, como en el encuentro de dos subjetividades; $y$, aún mejor, en la posesión de la una por la otra" (pág. 43). 
sensible en nuestro cerebro? Este reflejo unido, contrastado, con las imágenes reflejadas en los cerebros de Ios demás hombres que han vivido y que viven, es nuestro conocimiento del mundo, es nuestro mundo. ¿Es así, en realidad, fuera de nosotros? No lo sabemos, no lo podremos saber jamás.

-No veo claro. Todo eso me parece poesía (pág. 170).

Estos fragmentos "líricos" vienen a ocupar, en la narrativa modernista, el lugar que ocupaba en el discurso de la novela naturalista la descripción objetiva del medio ambiente ${ }^{10}$, cuyas fuerzas determinan al personaje.

La clave de estos fragmentos líricos, de estos instantes contemplativos en la novelística de Baroja, se encuentra, sin duda, en todos aquellos aspectos de la realidad que conmueven el corazón del artista y que le animan a la comunicación lírica con el alma del lector. Pero para apreciarlos y comunicarlos con efectividad y suficiencia estética, nuestro novelista apela a lo que llama "mi fondo sentimental", su capacidad de emocionarse ante la realidad. Lo explicó en 1925 desde las páginas de la Revista de Occidente, en diálogo con Ortega y Gasset:

Respecto a mí, yo he notado que mi fondo sentimental se formó en un período relativamente corto de la infancia y de la primera juventud, un tiempo que abarcó un par de lustros, desde los diez o doce hasta los veintidós o veintitrés años. En ese tiempo todo fue para mí trascendental; las personas, las ideas, las cosas, el aburrimiento; todo se me quedó grabado de una manera fuerte, áspera e indeleble (1925, pág. 92).

El novelista pondrá su acento lírico en aquellos elementos de la realidad que logren conmover su fondo sentimental, o bien que procedan directamente de él, un recuerdo de infancia, un paisaje soñado. Es lo que Baroja llamó "la extraña poesía de las cosas vulgares".

Al alba, salen al campo. No hay nadie en la isla. Va amaneciendo. El aire está puro y embalsamado; las hierbas, granizadas de flores. El sol comienza a brillar, la pradera ríe...

PARADOX.- Yo no comprendo la maldad, el odio, la guerra, ante un sol como éstc. 162).

Sirsom.- Es que usted es un poeta, un pobre hombre, Paradox (1906, pág.

Estos sentimientos emotivos hacia la realidad adquieren una dimensión profundamente ética en la narrativa barojiana. Siguiendo el dictado de Schopenhauer, la compasión, la piedad por los semejantes se convierten en un imperativo moral. Estas ideas, el rechazo de la hipocresía y la vanidad del mundo, y la primacía del

10 "Este naturalismo [...] todo lo fía a la existencia de una realidad unívoca anterior al texto ante la que sitúa la conciencia perceptiva del autor, escudriñadora de todos sus entresijos mediante una demorada y eficaz observación. Todo ello daráccomo resultado una reproducción veraz de aquel referente, gracias a la transparencia o adelgazamiento del medio expresivo propio de la literatura, el lenguaje, y a la sinceridad del artista" (Villanueva, 1992, pág. 32). 
sentimiento sobre la razón a la hora de percibir la realidad, se traducirán en una serie de preferencias temáticas que no vamos a abordar aquí. Junto a los fenómenos naturales (paisaje, mar) y artísticos (las ciudades muertas), el vuelo lírico se alzará en la pluma barojiana cuando se aborden personajes desgraciados o desvalidos, golpeados por un sistema que les explota, les desprecia y les margina, como los obreros, los mendigos, las prostitutas, los ancianos y los niños.

Sin embargo, será la naturaleza, y más concretamente el paisaje de las tierras de España, el tema dominante de los instantes líricos barojianos. Es ya un tópico, al hablar de este aspecto fundamental de nuestra narrativa modernista, el decir que los escritores del 98 son "los inventores del paisaje español", según la expresión de Laín Entralgo (págs. 15-29). Ello no es del todo cierto, pues, como sabemos, en la novela naturalista las descripciones paisajísticas aparecen esporádicamente, aunque con una función de mero escenario o decorado de la trama principal, según era costumbre en la preceptiva clásica" . Pero Gérard Genette ha considerado una segunda función de estas descripciones, "d'ordre à la fois explicatif et symbolique", que consisten "à révéler et en même temps à justifier la psychologie des personnages, dont ils sont à la fois signe, cause et effet" (1969, págs. 58-59). La descripción como revelación del personaje, que guarda una importante relación de orden semántico con la narración, es un efectivo descubrimiento estético de los más sagaces escritores naturalistas, como Galdós y, sobre todo, Leopoldo Alas (Sotelo Vázquez, 1989a y 1989b).

Lo que sí es realmente nuevo en la literatura modernista es la autonomía estética que adquiere el paisaje español. Se puede apreciar una especie de arrobamiento lírico del narrador en las impresiones paisajísticas, que superan claramente la función de mero escenario que éstas desempeñaban en la novela realista. El interés por el paisaje que sienten los escritores del fin de siglo se relaciona, por un lado, con la actitud antiindustrialista que domina las preferencias temáticas de la época, y por otro, con la idea axilar del ensayo de Unamuno En torno al casticismo (1895), la idea de la intrahistoria, de la tradición eterna. El paisaje castellano se convertirá en materia literaria porque es el medio ambiente donde se ha desarrollado su casta histórica, y recuperando sus cualidades estéticas se intentarán recuperar los valores espirituales eternos, universales y cosmopolitas, que forman parte del espíritu nacional. Pero además, la contemplación de su monotonía, de su sequedad y de sus líneas rectas interminables invitarán a la reflexión interior, al ahondamiento en las verdades del alma. El paisaje funcionará en la narrativa modernista, de esta manera, como correlato objetivo del alma agónica del personaje. Se trata del procedimiento básico de la narrativa simbolista, cuyo hallazgo debemos, en la literatura

11 Como ha explicado Gérard Genette, en la retórica clásica "la description étendue et détaillée apparaît ici comme une pause et une récréation dans le récit, de rôle purement esthétique, comme celui de la sculpture dans un édifice classique" (1969, pág. 58). 
española, a Clarín, y que consiste en la traducción o expresión de los sentimientos más hondos del alma objetivándolos en un objeto, en una persona, en un escenario o incluso en una actitud o en una acción, sacándolos fuera del reino interior del yo, exteriorizándolos en una imagen perceptible del mundo exterior (Ordóñez García, en prensa). La idea del paisaje o de la naturaleza como correlato del personaje contemplativo se debe, no obstante, a Schopenhauer:

Si nos absorbemos y nos sumimos en la contemplación de la naturaleza tan profundamente que ya no existamos más que a título de puro sujeto consciente, sentiremos al punto que somos en tal calidad la condición, por decirlo así, el sostén del mundo y de toda existencia objetiva; porque la existencia objetiva no se presenta ya más que a título de correlativo de nuestra propia existencia (pág. 256).

Otra importante preferencia temática de los fragmentos líricos barojianos son las ciudades muertas castellanas, como Toledo, Labraz o Córdoba, que también tienen mucho que ver con el procedimiento del correlato objetivo simbolista y con el pensamiento de Schopenhauer ${ }^{12}$. Como en Proust, la descripción en Baroja "es menos una descripción del objeto contemplado que un relato y un análisis de la actividad pereeptiva del personaje que contempla" (Genette, 1972, pág. 157). El análisis de la perspectiva narrativa, por tanto, se hace imprescindible para deslindar el fragmento lírico del resto del relato.

\section{IV}

La instancia narrativa que voy a utilizar para intentar señalar los límites externos del fragmento lírico es la perspectiva narrativa: el foco o punto de percepción restrictivo de la realidad (Genette, 1972, págs. 241-248). Ya hemos aludido a cómo la intuición está íntimamente relacionada con la sinceridad y la extrema sensibilidad de nuestro escritor, los nortes de su personalidad, y también al imperativo de interiorización en la novela que caracteriza al Modernismo. La realidad se transmite al lector no haciendo un supremo esfuerzo de mimesis, mediante la utilización de una focalización cero, sino que se filtra o tamiza a través de la conciencia de un personaje, que la percibe y que nos dicta, con su voz o con la del narrador, sus impresiones subjetivas; se utiliza, en fin, una focalización interna.

Las principales personalidades del fin de siglo español, como Clarín, Unamuno o Maragall, habían insistido en la necesidad de la interiorización, de la

12 Hablando del libro que originó este tópico modernista - Brujas la muerta (1892), de Rodenbach -, ha explicado Lozano Marco: "ganado por el pesimismo del filósofo alemán, la ciudad muerta no es sólo el resultado del mundo como representación de Hugues, sino también cl lugar privilegiado donde podría escapar a las incitaciones de la vida: es lección de silencio y calma, ejemplo de resignación, consejo de piedad y austeridad; un espacio donde se resume la aspiración schopenhaueriana, la mutilación de los deseos, beneficiándose de la influencia pálida y tranquilizadora de Brujas en la serena espera de una buena muerte" (1995, pág. 163). 
subjetivización, de la expresión de la intimidad del poeta, como único medio para alcanzar la expresión artística estéticamente suficiente. A propósito de la novela, Ricardo Gullón afirma: "Como en la poesía, la verbalización da por supuesta en la novela lírica la presencia de un agente, narrador o personaje, en quien se opera la transformación del objeto percibido: algo así como su exaltación o transfiguración" (pág. 18). Baroja expresa en Camino de perfección la misma idea, y con ello nuestro novelista marca ya en 1902 sus distancias respecto a la novela realistanaturalista, a la vez que se aproxima a sus compañeros de generación:

Lo que sí creo es que el arte, eso que nosotros liamamos así con cierta veneración, no es conjunto de reglas, ni nada; sino que es la vida: el espíritu de las cosas reflejado en el espíritu del hombre. Lo demás, todo eso de la técnica y el estudio, todo eso es m... (1902, pág. 14)

Todos los fragmentos líricos barojianos, con la excepción, como es evidente, de las dos novelas dramatizadas de 1900 y 1906, presentan esa focalización interna. A través del estado de ánimo de un personaje, generalmente el personaje principal o protagonista de la acción narrativa, se plasma en el texto la realidad, que es únicamente la representada en su conciencia. Este personaje se mueve en un mundo que sólo conocemos a través de sus percepciones, de sus impresiones; por supuesto, también hemos de tener en cuenta la instancia de la voz que narra, ya que, cuando el personaje asume la doble naturaleza de focalizador y narrador, esa percepción se plasma en el texto sin la mediación de un narrador heterodiegético, ajeno a la historia, aumentando así el tono lírico.

En los textos se hace patente esa focalización interna mediante el uso de los verbos que indican percepción (mirar, contemplar, oír, parecer), y con ello, el objeto de esa percepción se contagia del estado de ánimo del personaje. Silvestre Paradox, en uno de los momentos más dramáticos de la historia de sus desdichas, percibe así el paisaje madrileño desde su ventana:

Asomado a la ventana solía mirar distraído los paisajes de tejas arriba, las chimeneas que se destacaban en el cielo gris, echando el humo sin fuerza, débil, anémico, en el aire plomizo de las lúgubres tardes de diciembre. Las tejavanas y las guardillas parecían casas colocadas encima de los tejados, que formaban pueblos con sus calles y sus plazas, no transitados más que por gatos. Entre todas aquellas ventanas de tabucos, de miserables sotabancos, de hogares pobres, sólo en una se traslucía algo asi como una lejana manifestación de alegría de vivir: era en una ventana en cuyos cristales se veían cortinillas, y en el alféizar dos cajones de tierra que en el verano habían tenido plantas de enredaderas y guisantes, que aún quedaban como filamentos secos y negruzcos colgados de unos hilos.

$\mathrm{Al}$ anochecer, sobre todo cuando el cuarto se llenaba de sombras, le acometía a Silvestre una amargura de pensamiento que subía a su cerebro como una oleada, náuseas de vivir, náuseas de la gente y de las cosas, y se marchaba a la calle y le disgustaba todo lo que pasaba ante sus ojos, y recorría calles y calles tratando de mitigar lo sombrio de sus pensamientos con la velocidad de la marcha (1901, págs. 136-137). 
Observando los campos semánticos de adjetivos y nombres, se puede apreciar la traslación a la realidad de ese estado de ánimo del personaje.

En otras ocasiones Baroja opone la desesperanza, el desengaño, la abulia de su personaje a un paisaje, una naturaleza cuyas características son la vitalidad, el movimiento, el colorido, el misterio. Se trata, como hemos visto más arriba en el pasaje citado de Camino de perfección, de una íntima comunión entre el espíritu de las cosas y el cspíritu del hombre. Nos encontramos, entonces, ante una utilización simbólica de la realidad, ante un correlato objetivo, como ya hemos explicado. Por ejemplo:

Se veía el pueblo desde lejos sobre una loma. Por encima de él, nubes espesas y plomizas formaban en el horizonte una alta muralla, encima de la cual parecian adivinarse las torres y campanarios de alguna ciudad misteriosa, de ensueño.

Aquella masa de color de plomo, estaba surcada por largas hendeduras rojas que al reunirse y ensancharse parecian inmensos pájaros de fuego con las alas cxtendidas.

La masa azulada de la sierra se destacó al anochecer y perfiló su contorno, línea valiente y atrevida, detallada en la superficie más clara del cielo.

Obscureció; lo plomizo fue tomando un tono frío y gris; comenzó a oirse a lo lejos el tañido de una campana; pasó una cigüeña volando... (1902, pág. 69)

Esa naturaleza despierta y viva sugiere al abúlico Fernando Ossorio un mundo de misterios y ensoñaciones, el forêt de symboles del que hablaba Baudelaire en su soneto "Correspondances". Esa contemplación de la naturaleza imbuye de ánimo al protagonista y forma parte de ese "camino de perfección" que ha emprendido; como se nos dice más adelante: " $i Q u e ́$ impresión de vaguedad producían el cansancio y la contemplación en su alma!" (pág. 81). Otro ejemplo, esta vez de $E l$ mayorazgo de Labraz (1903), nos describe el interior de una casa, único testigo de los frenéticos amores de Micaela y Ramiro:

En aquellas habitaciones desoladas por donde paseaban Micaela y Ramiro, el eco repetía el ruido de sus pasos, el murmullo de sus voces y el estallido de sus besos; los anchos tablones del suelo se bamboleaban con las pisadas, exhalando tristes quejidos. El aire silbaba en los oscuros corredores, las puertas gemían al abrirse, y al cerrarse golpeaban la desquiciada jamba, que se deshacía en polvillo amarillento (1903, pág. 194).

Los campos semánticos se relacionan con los de la actividad amorosa; Baroja no describe detalladamente, sino que prefiere sugerir esa actividad con una expresión que hace patente la correspondencia entre realidad externa y conciencia interior. En muchas ocasiones, la caracterización del personaje perceptor pierde profundidad, a la vez que la gana la subjetivización de la realidad; según Ricardo Gullón, "el personaje pierde su rotundidad, no su humanidad; más delgado, transparente casi, es una luz, una voz, unos ojos, metáfora o sinécdoque de sí mismo, no forzadas por el novelista a dar de sí más de lo que normalmente ceden" (pág. 26). Podemos, por lo tanto, hablar de limitación de esa realidad, de mundo como representación, ya que únicamente es la que percibe el individuo, este nuevo tipo de personaje excepcional que es el héroe decadente. 
Es muy interesante comparar esas percepciones de la realidad conforme evoluciona ese estado de ánimo; así, en Camino de perfección, en contraste con el fragmento que hemos visto, los capítulos finales nos muestran un Ossorio a punto de casarse con Dolores, radiante de felicidad, que a la vez coincide con la llegada de la primavera:

Como si en mi alma hubiese un río interior detenido por una presa y al romperse el obstáculo corriera el agua alegremente, así mi espíritu, que ha roto el dique que le aprisionaba, dique de tristeza y de atonía, corre y se desliza cantando con júbilo su canción de gloria, su canción de vida; nota humilde, pero armónica en el gran coro de la Naturaleza Madre (1902, pág. 279).

De manera parecida, Quintín, en La feria de los discretos, al enterarse de que su amada Rafaela está ya comprometida, "sentía momentos de tristeza, de rabia, de amor propio herido y maltrecho [...] ¡ ¡Cómo le abrumaba aquella primavera andaluza! Vagaba de aquí para allá sin plan, sin objeto, sin rumbo. [...] Quintín vagaba de un lado a otro rumiando sus tristezas". La descripción de Córdoba, revestida momentáneamente de los atributos del alma desolada del personaje, revela claramente su condición de "ciudad muerta":

El sol inundaba las calles silenciosas, desiertas; el cielo azul, de un azul puro, sin transparencia, parecía algo compacto, una gran turquesa o un gran zafiro, en donde se empotraran tejados y torres, azoteas y terrazas.

Todo daba una impresión de letargo profundo... Las casas blancas, azules, amarillas, de un rosa pálido, de crema, cerradas herméticamente, parecían abandonadas; los zaguanes, como pozos de sol, cegaban por la reverberación de la luz en las paredes. En los callejones, tenebrosos, angostos, llenos de sombra, se sentía un frío húmedo, de cueva... En unas partes y en otras dominaba el silencio y la soledad; en alguna rinconada, un borriquillo, atado a una reja, permanecía inmóvil, un perro famélico escarbaba un montón de basura, o un gato asustado corría, con la cola erizada, hasta desaparecer en un escondrijo. [...]

Una calma abrumadora, una soñolencia fatigosa pesaba sobre el pueblo, y en medio de esta calma, de este silencio de muerte, sonaba una campanada aquí, otra allá, y todas a cuál más lánguidas y tristes... (1905, págs. 132-134)

Cuando, al final del relato, vuelve al lado de Remedios, mujer que le ha inspirado súbitamente un sincero amor, la percepción de la realidad cambia: "La noche estaba clara, templada y dulce. La luna argentaba las colinas lejanas; un ruiseñor cantaba suavemente en la oscuridad” (1905, págs. 299-300). Procesos análogos los podemos observar en todas las novelas de Baroja.

En una novela como Las inquietudes de Shanti Andía, en la que se utiliza ya la voz homodiegética, el personaje nos habla con su voz, sin la mediación de un narrador ajeno a la historia. Antes de comenzar a relatarla, todavía situado en el tiempo de la narración, Shanti nos declara:

Tengo que hablar de mí mismo; en unas memorias es inevitable.

Además de mi indolencia, exagerada un tanto por mis convecinos los luzarenses para presentarme como un tipo estrambótico, soy un sentimental y un contemplativo. 
Me gusta mirar, tengo la avidez en los ojos; me quedaría contemplando horas y horas el pasar de una nube o el correr una fuente. Quizá viviendo en tierra se hubiera desarrollado en mí el sentido musical, como en muchos de mis paisanos; en el mar se ha ampliado, se ha alargado mi sentido óptico.

Muchas veces me he figurado ser únicamente dos pupilas, algo como un espejo o una cámara oscura para reflejar la Naturaleza (1911b, págs. 51-52).

Metanarrativamente, Baroja explica aquí su teoría del personaje contemplativo. Más adelante, a propósito de sus impresiones sobre el mar vasco y el cabo de Frayburu, confiesa nuestro escritor las limitaciones de la percepción humana, ya que cada persona recibe unas impresiones diferentes de la realidad; pero acaso la percibida por cada uno sea la verdadera realidad:

El hombre, sin duda, no está organizado para comprender lo trascendental de lo que es extraño a él. Así presta sus designios a las cosas; así supone que el sol está hecho para alumbrarle y las estrellas para alumbrar su noche.

Todo lo vaciamos en el molde de nuestro espíritu; fuera de este pequeño molde, no tenemos nada para asir y comprender las cosas que pasan por delante de nosotros. Por eso damos a todo el universo, desde la gota de agua hasta Sirio, una intención humana (1911b, pág. 170).

Estas palabras son fácilmente relacionables con las de Miguel de Unamuno en el "Prólogo" a sus Tres novelas ejemplares y un prólogo (1920), donde se pregunta: “Cuál es la realidad íntima, la realidad real, la realidad eterna, la realidad poética o creativa de un hombre?", para más tarde responder que "la realidad es la íntima", la que cada individuo siente como verdadera en las honduras de su alma (págs. 48 y 52). La realidad filtrada por la conciencia de un personaje (trasunto literario de la realidad pasada a través del filtro de las percepciones del autor), correlato objetivo de su intimidad, es la que nos dan los fragmentos líricos barojianos. Es la forma literaria del mundo como representación de Schopenhauer.

No cabe duda de que el pensamiento de Schopenhauer y la nueva epistemología inspirada en su consideración del "mundo como representación" constituyen una de las influencias filósoficas más importantes del Modernismo español, y fue advertida en su tiempo por la crítica más sagaz. Así, y junto a doña Emilia, como hemos visto, Unamuno y Llanas Aguilaniedo.

Miguel de Unamuno señaló certeramente en su reseña de Vidas sombrías (Las Noticias, 9-VI-1900), libro que coleccionaba cuentos de Baroja ya publicados desde 1893, la profunda huella del filósofo de Danzig, junto a la de Dostoievski y Poe: "hay algo de doloroso, un cierto ensañamiento en la observación menuda, en los relatos que componen Vidas sombrías" (1993, pág. 238). Ciertamente, abundan las descripciones de los ambientes marginados de los suburbios obreros, aprendida en libros como Tiempos difíciles (1854), de Charles Dickens, o Humillados y ofendi- 
dos (1866), de Dostoievski, temas como la fábrica, el obrero, la mendicidad..., que despiertan en el artista un hondo sentimiento de piedad y de compasión, siguiendo la consideración de Schopenhauer, en Los dolores del mundo, de que "una piedad sin límites por todos los seres vivos es la prueba más firme y más segura de la conducta moral" (Lozano Marco, 1988, pág. 25) ${ }^{13}$. Ante el ansia de reposo espiritual, de ataraxia, de anulación de la voluntad, Unamuno señala, refiriéndose a nuestro filósofo: "Pero, ¿no habrá algo aquí de sugestión libresca? ¿No será esto en parte eco de lecturas de libros en que se predica el nirvana?" (1993, pág. 232). Quien tradujera un importante texto de Schopenhauer ese mismo año de 1900 concluye su análisis con una importante consideración de la prosa barojiana: "donde Baroja resulta es en las impresiones vagas, misteriosas o fantásticas [...], en las narraciones casi sin asunto, en las notas de íntima melodía" (pág. 240). Destaca, pues, su prosa lírica y su sinceridad como lo más valioso de Baroja.

El dolor y sus consecuencias como elemento estético de los nuevos narradores del 900 es una constante que ya advirtió Llanas Aguilaniedo en su tempranísimo estudio Alma contemporánea (1899):

La inmensa mayoría de los literatos del día dejan ver claramente en sus producciones un fondo de amargura, de indiferencia y de escepticismo, sincero unas veces, soñado o expuesto por tendencia habitual otras. Tonos tristes y dulcemente melancólicos matizan la producción, comunicándola carácter, iguales siempre hasta la monotonía; la mente del autor gira de continuo en torno de los mismos problemas con obsesión, imposible de desvanecer, que se deja sentir hasta en las palabras quc emplea, algunas de las cuales se repiten en el escrito con insistencia de monodeísmo (pág. 111).

El pensamiento de Arthur Schopenhauer fundamentó con su armazón teórico el gran conflicto del novelista postnaturalista, compaginar el mundo externo y la realidad interior, es decir, la esencial necesidad de mimesis que el Naturalismo había aportado a la novela con las zozobras y vaivenes del espíritu moderno, con las inquietudes y las más hondas verdades del alma humana. El instante contemplativo schopenhaueriano, con todo lo que implica de dejación de la voluntad, olvido de la razón y fusión esencial del yo con la naturaleza en una integral comunión espiritual, se halla detrás del procedimiento básico de la novela simbolista, el correlato objetivo. Y el pensamiento todo del autor alemán ilumina no solamente la ideología del autor que se esconde tras la máscara del narrador y del personaje en las novelas barojianas, sino que también explica toda una serie de innovaciones técnicas necesarias para expresar en el texto narrativo la nueva epistemología. Pionero de esta tendencia ha sido Inman E. Fox, al demostrar, en su análisis de $E l$ árbol de la ciencia, que "la estructura de la novela no es más ni menos que una

13 Juan Oleza también ha destacado esta preferencia por los ambientes y personajes desheredados y marginales, procedente de la narrativa rusa, en la novela espiritualista del último Galdós (1988, págs. 433-436). 
proyección novelística de la principal obra del alemán, El mundo como voluntàd y representación" (pág. 169). Implicaciones estructurales y, como espero haber probado en este estudio, también estilísticas en los fragmentos líricos que remansan ocasionalmente las narraciones del guipuzcoano.

Pero la proyección de la interioridad o intimidad del personaje en la realidad externa no consiste tan sólo en la simple contaminación de esta última por las sensaciones y estados anímicos, sino también en el poder de significación, en las íntimas correspondencias del alma con el mundo, y el ansia de autoconocimiento del héroe decadente implica la contemplación desinteresada y la captación del sentido oculto, de la esencia permanente, intemporal, eterna y verdadera, de la dimensión espiritual del mundo exterior. Como afirma Schopenhauer en un fragmento de Parerga y Paralipomena:

La palabra del hombre es el material más duradero. Cuando un poeta traduce su más fugitiva impresión en palabras que le son exactamente apropiadas, esa impresión vive durante largos siglos, y se reanima sin cesar en el lector que es accesible a ella (1995, pág. 67).

En los fragmentos líricos barojianos nos encontramos con la expresión simbolista en toda su plenitud, ideal del Modernismo, como explicó Llanas Aguilaniedo:

El ideal de las literaturas del día es sugerir, no precisamente expresar, dar idea de una cosa sin nombrarla; llevar al alma la impresión de una melodía definida a través de notas que no hacen más que despertar la idea de ella y acompañarla (pág. 75).

Expresión sugestiva cuyo único objetivo es lograr la comunicación simpática del alma del lector con la del autor, que ambas vibren al unísono, que los sentimientos se transmitan de forma efectiva.

Por lo tanto, y al igual que en la poesía lírica, el lenguaje, la expresión, llamará la atención sobre sí misma, adquiriendo un protagonismo del que carecía en la novela naturalista. Su premisa básica, de clara raigambre positivista, consistente en que la lengua puede copiar la realidad, y que la representación textual de esa realidad puede lograrse mediante el uso de una lengua literaria unívoca y rectilínea, que imite con su sintaxis hipotáctica la ordenación o jerarquía natural del mundo, va a ser claramente superada gracias a las teorías del Simbolismo francés, que pretenden potenciar las capacidades sugestivas del lenguaje. Ahora "el lenguaje no puede reproducir el mundo, el lenguaje es sistemático y el mundo no; el lenguaje sólo puede dar testimonio de la conciencia individual, porque en ella se funda, y no en el mundo" (Lázaro Carreter, pág. 149). En los fragmentos líricos de Baroja importa más el tejido discursivo que la realidad que pretende reflejar; en palabras de Germán Gullón, "el poder significativo de la novela moderna emana de su propio tejido verbal" (1990, pág. 30). En la narrativa modernista es ya el texto y no la realidad 
representada quien obtiene la primacía de la verdad, por encima de la verdad que refleja ${ }^{14}$.

\section{BIBLIOGRAFÍA}

ALAS, Leopoldo. (1884-85). 19884. La Regenta, ed. de Gonzalo Sobejano, Madrid, Castalia, 2 vols.

— (1892). 1991. Ensayos y revistas, prólogo de Antonio Vilanova, Barcelona, Lumen.

ALBERICH, José. (1961). 1974. "La biblioteca de Pío Baroja", en Francisco Javier MARTÍNEZ PALACIO (ed.), Pio Baroja, Madrid, Taurus, págs. 263 282.

ASÚN, Raquel. 1981-82. "La editorial La España Moderna", Archivum, XXXIXXXII, págs. 133-199.

- 1991 "El europeísmo de La España Moderna", en Estudios y ensayos, Universidad de Alcalá de Henares, págs. 221-235.

BAROJA, Pío. (1901). 1989. Aventuras, inventos y mixtificaciones de Silvestre Paradox, ed. de Inman E. FOX, Madrid, Espasa-Calpe.

- (1902). 1993. Camino de perfección, Madrid, Caro Raggio.

- (1903). 1972. El mayorazgo de Labraz, Madrid, Caro Raggio.

- (1905). 1986. La feria de los discretos, Madrid, Alianza.

- (1906). 1991. Paradox, rey, ed. de Jesús Ma Lasagabaster, Madrid, EspasaCalpe.

- (1910). 1975. César o nada, Madrid, Caro Raggio.

- (1911a). 19906. El árbol de la ciencia, ed. de Pío Caro Baroja, Madrid, Caro Raggio-Cátedra.

- (1911b). 1990. Las inquietudes de Shanti Andía, ed. de Darío VILLANUEVA, Madrid, Espasa-Calpe.

- (1917). 1985. Juventud, egolatría, prólogo de Julio Caro Baroja, Madrid, Caro Raggio.

14 Debo agradecer a Marisa Sotelo Vázquez, profesora de la Universidad de Barcelona, y a Aurora Vall i Casas, del Institut d'Estudis Catalans, su amabilidad al haberme facilitado algunos textos sin los cuales este trabajo no habría sido posible. 
- (1925). 1987. "Prólogo casi doctrinal sobre la novela", en La nave de los locos, ed. de Francisco Flores Arroyuelo, Madrid, Caro Raggio-Cátedra, págs. 63-95.

- (1948). 1983. Desde la última vuelta del camino (Memorias) 5. La intuición y el estilo, Madrid, Caro Raggio.

BONET, Laureano. 1984. "La música como voz callada en La Regenta", Los Cuadernos del Norte, XXIII, págs. 64-69.

- 1985. "Temporalidad, memoria y ensueño en la obra de Clarín", en Antonio Vilanova (ed.), Clarin y su obra en el centenario de "La Regenta", Universitat de Barcelona-PPU, págs. 121-143.

FOX, E. Inman. (1963). 1988. "Baroja y Schopenhauer: El árbol de la ciencia", en Ideología y política en las letras de fin de siglo (I898), Madrid, Espasa-Calpe, págs. 157-175.

GENETTE, Gérard. 1969. Figures II, París, Éditions du Seuil.

- (1972). 1989. Figuras III, Barcelona, Lumen.

GULLÓN, Germán. 1990. "Introducción” a Miguel de Unamuno, Niebla (1914), Madrid, Espasa-Calpe, págs. 9-32.

- 1992. La novela moderna en España (1885-1902) 1. Los albores de la modernidad, Madrid, Taurus.

GULLÓN, Ricardo. 1984. La novela lírica, Madrid, Cátedra.

LAÍN ENTRALGO, Pedro. (1947). 19707. La generación del noventa y ocho, Madrid, Espasa-Calpe.

LÁZARO CARRETER, Fernando. 1990. De poética y poéticas, Madrid, Cátedra.

LLANAS AGUILANIEDO, José María. (1899). 1991. Alma contemporánea, ed. de Justo BROTO SALANOVA, Huesca, Instituto de Estudios Altoaragoneses.

LOZANO MARCO, Miguel Ángel. 1988. La literatura como intensidad. Alicante, Caja de Ahorros Provincial.

- 1995. "Un topos simbolista: la ciudad muerta", Siglo Diecinueve, 1, págs. $159-175$.

MAINER, José-Carlos (1974). 19875. La Edad de Plata (1902-1939). Ensayo de interpretación de un proceso cultural, Madrid, Cátedra.

MARTÍNEZ RUIZ, José. (1902). 1989'. La voluntad, ed. de E. Inman Fox, Madrid, Castalia. 
OLEZA SIMÓ, Juan. 1988. "Su único hijo versus La Regenta: una clave espiritualista", en Yvan Lissorgues (ed.), Realismo y Naturalismo en España en la segunda mitad del siglo XIX, Barcelona, Anthropos, págs. 421-444.

- 1989. "Espiritualismo y fin de siglo: convergencia y divergencia de respuestas", en Francisco Lafarga (ed.), Imágenes de Francia en las letras hispánicas, Barcelona, PPU, págs. 77-82.

ORDÓÑEZ GARCÍA, David. (En prensa). "La superación del Naturalismo en Leopoldo Alas: el correlato objetivo en Doña Berta (1891)", España Contemporánea.

PARDO BAZÁN, Emilia. 1904. "La nueva generación de novelistas y cuentistas en España", Helios, XI, págs. 257-270.

SANTIÁÑEZ-TIÓ, Nil. 1995. "El héroe decadente en la novela española moderna (1842-1912)", Boletín de la Biblioteca Menéndez Pelayo, LXXI, págs. 179216.

SCHOPENHAUER, Arturo. (1819). 1930. El mundo como voluntad y representación, Madrid, Caro Raggio.

- (1995). Escritos literarios, introducción de Ángel Gabilondo, Guadalajara, Lípari Ediciones.

SOBEJANO, Gonzalo. 1967. Nietzsche en España, Madrid, Gredos.

- 1988. "El lenguaje de la novela naturalista", en Yvan Lissorgues (ed.), Realismo y Naturalismo en España en la segunda mitad del siglo XIX, Barcelona, Anthropos, págs. 583-615.

SOTELO VÁZQUEZ, Adolfo. 1989a. "Escritura, descripción y relato en La Regenta: el salón de doña Petronila", Co-Textes, 18, págs. 23-42.

- 1989b. "La descripción como revelación del personaje en la novela realista: Ana Ozores y la insignificancia", Letras Peninsulares, 2, págs. 7-18.

- 1991. "Clarín en torno a Realidad (1889)", Revista Hispánica Moderna, XLIV, págs. 35-47.

- 1995. "Cambio de luz, palimpsesto". España Contemporánea, VIII, págs. 101-116.

UNAMUNO, Miguel de. (1902). 1992. Amor y pedagogía, ed. de Ana Caballé, Madrid, Espasa-Calpe.

- (1913). 1986. Del sentimiento trágico de la vida, prólogo de Fernando SAVATER, Madrid, Alianza.

- (1920). 1990. Tres novelas ejemplares y un prólogo, ed. de Ciriaco Morón Arroyo, Madrid, Espasa-Calpe. 
- 1993. Artículos en "Las Noticias" de Barcelona (1899-1902), ed. de Adolfo Sotelo Vázquez, Barcelona, Lumen.

VILANOVA, Antonio. 1989. "La teoría nivolesca del bufo trágico", en Dolores Gómez Molleda (ed.), Actas del Congreso Internacional. Cincuentenario de Unamuno, Universidad de Salamanca, págs. 189-216.

VILLANUEVA, Darío. 1992. Teorías del realismo literario, Madrid, Espasa-Calpe. 